DOI:10.31866/2410-1915.22.2021.235894

UDC 008:17.022.1](477):[316.774:070:004](100)

\title{
EVOLUTION OF THE CULTURAL MODEL OF THE UKRAINE IMAGE IN THE INTERNATIONAL INFORMATION SPACE
}

\section{Oksana Koshelieva}

\author{
Senior Lecturer, \\ ORCID: 0000-0002-1653-2103, renisenb@ukr.net, \\ Kyiv National University of Culture and Arts, \\ 36, Ye. Konovaltsia St., Kyiv, 01133, Ukraine
}

\author{
For citations: \\ Koshelieva, O. (2021). Evolution of the Cultural Model of the Ukraine Image in the International \\ Information Space. Culture and Arts in the Modern World, 22, 59-70. https://doi.org/10.31866/2410- \\ 1915.22.2021.235894.
}

The purpose of the article is to determine the sociocultural determinants of the transformation of Ukraine foreign image under the influence of domestic and foreign political events and the state of its coverage in the information space; to ascertain the evolution of the cultural model of the image of Ukraine in the international information space. The research methodology consists in the use of interdisciplinary methods and approaches to identify information and communication technologies aimed at the formation of the international image of Ukraine; the principle of historicism allowed determining the stages of changes in the information space and the transformation of the geopolitical situation around Ukraine; the structural and comparative methods were used to determine the international media positions on Ukraine, their influence on the formation of its image. The scientific novelty of the research is in the presentation of the Ukraine image as an expression of the mentality of a particular cultural and historical community, an indicator of cultural meanings, unique design, mechanism of realisation of a national culture through a set of sign objectivations formed within a particular cultural and historical space and consolidated in the mental representations of individuals. Conclusions. It is proved that the negative image of Ukraine created by Western media affected the development of its tourism sector, the promotion of national cultural heritage and the investment climate significantly. The modern image of Ukraine is undergoing reformatting; there are significant cultural, political, and economic changes. The cultural model of the positive image of Ukraine in the international information space is determined by a properly structured state cultural policy and the effective use of modern image-making tools that can set it on the path of cultural, political and economic stabilisation.

Keywords: international image; national culture; information space; Ukraine; cultural policy; media 


\section{Introduction}

The modern development of the information society of Ukraine dictates new approaches to the political self-organisation of citizens and the formation of the state image. In the period of globalisation, the country's image is an important factor in international relations and an indicator of the international community's trust in a particular country. Furthermore, it contributes to the protection of national cultural treasures. The success of foreign policy and the development of trade and economic, sociocultural relations with other countries depend on a positive international image; it also helps to "consolidate" political success on the world scene. That is why the formation and implementation of an effective cultural policy to create a positive image, which should not only serve as a benchmark for future development but also present Ukraine in the world, should be an important strategy of the Ukrainian authorities. An important experience of changing the image of Ukraine in the international information space is the events of 2010-2014.

Recent research and publications analysis. In the context of political self-affirmation, self-identification and self-expression, Ukraine needs to continue developing communication technologies and improve external information flows purposefully, thereby forming an international information space in which the creation of a positive image occupies a prominent place. In the cultural space, an image is determined by encoding, consolidating, transforming, and translating cultural meanings through figurative and sign objectivations.

Many researchers have paid attention to forming the international political image of the leading countries of the world and Ukraine. In particular, the expert in the field of strategic communications, D. Bohush (2010), analysed the international image of Ukraine after the 2010 elections and conducted operational monitoring of influential global media in 2000-2009. Furthermore, experts' forecasts on the development of the political situation in the short and long term perspective of the Ukrainian Centre for Independent Political Research are found in N. Hasanenko's (2002) study Political Risk of Investment Activities in Ukraine. At the same time, it is important to understand political risks, which, according to A. Gorshkova's observations, are determined by "the probability of adverse consequences of political decisions made under conditions of uncertainty, lack of resources (time, information, etc.)", which can lead to the probability of fulfilment of undesirable events (Gorshkova, 2001).

Determining the state political image, D. Olshanskii notes that the supposed image of a certain state is formed in the minds of citizens of the country and foreign audience in the process of communicative interaction of subjects of economic, social and political life both inside and outside the country (Ol'shanskii, 2002, p. 166). O. Shvets' work (2006) is devoted to the formation of the political image of Ukraine in the international information space. At the same time, "the perception of Ukraine abroad remains spontaneous and fragmentary", so the formation of the image of the country should be consolidation of actions that reflect the strategy of Ukraine (Hastynshchykov, 2010). O. Shchurko's opinion (2007) that the attractiveness of the international image 
of a country depends on the influence of regional peculiarities, national traditions, historical memory, ideology is also important. All these components create a unified image, based on which a certain state among the entire world community is identified. At the same time, there are not enough studies devoted to analysing changes in the image of Ukraine in the international information space from the standpoint of culturology.

\section{Purpose of the article}

The purpose of the article is to determine the sociocultural determinants of the transformation of the international image of Ukraine under the influence of domestic and foreign political events and its coverage in the information space. The study's objective is to show the evolution of the cultural model of the image of Ukraine in the foreign information space. The research methodology consists of using interdisciplinary methods and approaches to identify information and communication technologies aimed at forming the international image of Ukraine. The principle of historicism allowed determining the stages of changes in the information space and the transformation of the geopolitical situation around Ukraine. The structural and comparative methods were used to determine international media positions on Ukraine, their influence on image formation, as well as to group and present factual material.

\section{Main research material}

The process of state image formation depends on many factors - the success of the foreign policy, economic efficiency, the specifics of society's mentality, the promotion of cultural heritage and others. As a factor of awareness of interactions between states by the world community, the political image reveals the scale and complexity of the construction of the modern political system in the era of transformation of new state images (Shvets, 2006). Therefore, the formation and further development of the image of Ukraine on the world stage requires strategic planning and organisation in many areas of political, economic, sociocultural activities. It is important to understand clearly that a favourable geographical location or the presence of a centuries-old historical and cultural heritage does not guarantee a positive perception of the country by the international community. National culture, as a subject of intercultural communication and, at the same time, an object of image communications, plays an important role in the implementation of both processes: in the first aspect, it serves as a context, the study of which becomes a necessary element of successful, non-conflict presentation of the nation and its culture abroad (intercultural communication), and in the second - as an image activity, national culture can form the basis of the content of image communications (representation of culture).

The international image based on external and internal factors, strengths and weaknesses of the state should take into account its capabilities, as well as threats to national security, the national democracy, spirituality and culture 
level. External factors represent foreign policy; national interests and priorities; membership in international organisations; development of relations with strategic partners; investment climate, etc. Internal ones are the welfare of the population; the democracy development and observance of constitutional rights, corruption, crime and the shadow economy; social well-being, etc. The strengths of Ukraine are favourable territorial location; high transport potential; ancient history and culture; high level of population education; space technologies; 30\% of the world rich black soil; ethnically and culturally homogeneous population. The weaknesses are instability and unpredictability in politics and economy; lack of a clear strategy for the country development; energy dependence on external energy sources; low economic growth; social and legal population insecurity; corruption in government bodies; infrastructure ageing; investor insecurity.

The threats to Ukraine are lack of guarantees of territorial integrity, delimitation and demarcation of borders with Russia, Belarus, Moldova, Romania have not been conducted yet; separatism; high population mortality; tuberculosis epidemic, the rapid spread of diseases; weak security of transport highways and pipelines. The positive perspective of Ukraine is determined by significant agricultural potential; regional leadership; the opportunity to turn into a cultural centre of Europe; production and sale of military equipment; resort areas (mountains, seas); participation in world projects on space programmes; equal membership with the European community; favourable investment climate; tangible and intangible cultural heritage as an element of the system of national values. Psychological aspects of the perception of a positive image of Ukraine are also important.

At the same time, it should be emphasised that the most significant negative factors of the international image of Ukraine are the unstable economy, the high corruption level, the low level of interest in the process of the formation of a modern brand of Ukraine as a promising European state and responsibility for it. In addition, the leading foreign media that do not have their correspondents in Ukraine often provide biased information about Ukraine (Hastynshchykov, 2010, p. 33). In particular, the researches of the Razumkov Centre show that the idea of foreign journalists about our country is superficial, fragmentary and mostly negative.

The English-language media (for example, New York Times, Global Post, The Nation, The Guardian, Minn Post) provide consumers with information that forms our state image as such that has just embarked on the path of democratic and economic reforms (without appreciable progress in recent years), where corruption has acquired a significant scale, human rights are not observed, and which, therefore, poses a risk to investment and business development (Zubyk, n.d.). North American media write mainly about the corruption of the Ukrainian government, the rise of crime, economic destitution; the topic of the Chernobyl disaster is also relevant. The positive image of Ukraine is promoted by the publications about important scientific and technical developments, sports achievements, cultural and artistic projects. The only negative information in such reports is about the miserable working conditions of Ukrainian scientists, athletes, artists and cultural figures. 
Ukrainian experts conduct a lot of monitoring of foreign media publications, based on which it is possible to trace changes in the information field around Ukraine. For example, after the 2010 presidential election, the operational monitoring of influential international media conducted by Bohush Communications showed that "when it's going about Ukraine, people often tend to mention Chernobyl, double-digit inflation, corruption, mafia schemes. However, it is also worth emphasising the strength of civil society, cultural life, freedom of speech, which cannot be compared to freedom in other post-Soviet countries, as well as the extraordinary ability, which the Ukrainian people have demonstrated in recent years to resolve contradictions and disagreements in the political scene peacefully. And indeed, these people learned more than anyone else in the $20^{\text {th }}$ century what violence means" (French monthly political newspaper Le Monde diplomatique) (Bohush, 2010). The Economist, an international weekly English-language newspaper, writes: "Ukraine remains a better and more civilised country than it was before the revolution. It has freer media and a more assertive citizenry. But those achievements have been won by the orange crowds, not by the politicians they once lionised" (Bohush, 2010).

Highlighting the development of democracy and freedom of speech in Ukraine, as well as the ability of civil society to resolve political contradictions peacefully, English-language media emphasise the inability of the Ukrainian political elite to confront the posed challenges: fight against corruption, economic development, social inequality, defending the country interests at the international level, etc.

Thus, in the Polish socio-political magazine Polska, it can be read: "Ukraine remains a weak democracy, and this country has been experiencing a real economic decline for a long time" (Bohush, 2010). Transparency International, the global civil society organisation leading the fight against corruption and conducting researches on corruption in the world, considers: "Political instability in Ukraine has led to political corruption involving the public and private sectors, which is accompanied by a high tolerance level among citizens for such practices and leads to a bad image" (Bohush, 2010).

The online magazine Eur Activ produces the following opinion: "Ukraine finds itself at yet another crossroads. The Orange Revolution may be a thing of the past, but its legacy will live on: its achievements should not be forgotten but built upon. It is up to Ukraine's leadership and political elites to create a climate of political and economic stability and deliver some tangible results to the long-suffering population, rather than continuing with the destructive infighting" (Bohush, 2010).

Euro 2012 hosting could be a positive step in promoting Ukraine on the international scene and the formation of opinion about it as a promising and hospitable state. Still, this event was overgrown with negative images in the foreign media, thereby forming a country's negative image.

Foreign media actively criticised Ukraine for racism, xenophobia and lack of a democratic regime. For example, in April 2012, the German magazine Der Spiegel accused Ukraine (article Visiting the Mafia) of gouging hotel prices. It 
broke off contracts with operators deliberately, which was the result of the influence of bandit groups (Bidder \& Eichhofer, 2012).

As a result, the number of people attending the championship was less than expected, especially from European countries. However, since the first day of the Championship, which was attended by 940 journalists from Europe and the CIS, the content of reports about Ukraine changed dramatically. $50 \%$ of the publications were positive, and 15\% were negative. Despite some shortcomings, Ukrainians were perceived as friendly and hospitable people. The visiting fans did not see the racism and riots that the media warned about. The New York Times noted the Ukrainian capital, Kyiv, as one of the most vibrant cities (Jones, 2012).

English journalist Oliver Holt in The Daily Mirror suggested apologising to Ukraine for accusations of racism (Holt, 2012). CNN noted that Euro 2012 is a great success for Ukraine and an effective platform for further promotion in the world. Forbes equated the level of the championship with that held in Belgium and the Netherlands in 2000 ("Svitovi ZMI", 2012).

The change in attitude towards Ukraine can also be seen in the example of the action held by English fans in Donetsk. In protest at comments made by former football player Sol Campbell not to travel to the country where racism and crime flourished, and from where, he said, they could come back in a coffin, the English walked along the streets of Donetsk with a coffin painted in the colours of the English flag and posters that read "Sol was wrong", "You're wrong, Campbell!", "We'll do what we want". All this shows that the Ukrainians managed to dispel the imposed image of a dangerous and criminal country (Harvey, 2012).

After all, Euro 2012 had a positive impact on the image within the country: $57.3 \%$ of Ukrainians consider that the championship contributed to the unification of the country, $40.0 \%$ of citizens felt proud of Ukraine, and $75.0 \%$ of respondents consider that the image of Ukraine in the world improved after Euro 2012 (Savchenko, 2012).

It should be noted that foreign media workers had a superficial and mostly biased view of our state at that time. The Western European media paid much attention to Ukrainian scientists' scientific and technical achievements, whom they considered worthy competitors; on the other hand, the level of poverty of the Ukrainian people and the constant attacks on freedom of speech by the authorities were always mentioned.

Regarding the media in Central and Eastern Europe, it is worth noting that they showed a better attitude towards Ukraine. However, the articles by journalists from these countries also concerned the Ukrainian mafia and information about Ukrainian illegal migrants. At the same time, led by the Polish media, they understood the need for our country's political and economic development to stabilise the regions of Central Europe. From the perspective of foreign journalists, Ukraine is a state with significant scientific and technical potential. Moreover, it is rich in resources (natural, human), and the main problem of Ukrainians is, in their opinion, the misuse and mismanagement of their resources.

According to foreign press reports, Ukraine continues to be a "post-Soviet" and "grey area" territory located between Russia and the European Union; the 
high level of corruption undermines the independence of the Ukrainian state, which is reflected in the level of life and "democratic imperfection" (Demokratychni initsiatyvy, 2013).

In 2013-2014, Ukraine became the object of special attention of the international community again, which was facilitated by the phenomenon of national resistance called Euromaidan. Wikipedia gave the following definition: "Euromaidan (also Euro Square, the 2013 Ukrainian Revolution, Revolution of Dignity) is a national-patriotic protest action in Ukraine, primarily, against corruption, social inequality, the arbitrariness of law enforcement agencies and special forces, as well as in support of the European vector of the foreign policy of Ukraine" ("Yevromaidan", 2020). This resonant event shook the whole world. A sharp information struggle between Ukrainian and foreign media began. Euromaidan was watched by international organisations and political leaders, political scientists and historians who tried to analyse this phenomenon, comparing it with other revolutions.

The events in Ukraine became the top topic of the world press - Euromaidan was on the front pages of newspapers and online media. For example, to understand better which the opposition seized buildings and which were under the control of the authorities, the world largest agency, the BBC, distributed a map of Kyiv among its readers. Leading English-language media (The Financial Times, The Washington Post, The Guardian, The New York Times, etc.) published information about the events in Ukraine almost daily. The political situation in our country became the main topic of the French newspaper, Le Monde, in which the article with the title Ukrainians Have Risen and the subtitle Europe Must Support the Democratic Aspirations of Kyiv was published. Mustafa Naiiem's face, a journalist of the online newspaper Ukrayinska Pravda and Hromadske TV, graced the cover of the Polish national newspaper Gazeta Wyborcza. The amount of material grew every day, and the media openly expressed support for the Ukrainian people in their struggle (Chornokondratenko, 2013).

It should be noted that the Euromaidan phenomenon has become international. The protesters gathered in the central squares of cities outside of Ukraine. In this way, Euromaidans were held in more than ten European cities (Paris, Berlin, Stockholm, Brussels, Vienna, Geneva, Strasbourg, Milan, Oslo, Bruges, Warsaw, London), as well as in Canada, the USA and Israel.

The image of Ukraine changed in the course of these events completely. In the West, they spoke of Ukraine as an independent free country and the "unconquerable Ukrainians". It should be noted that the cultural component, reaching the depth of historical memory, plays one of the leading roles in the structural model of the image of the country as a historical and culturally dominant, which has a symbolic character as an important element of the legitimacy of state power, state and territorial independence.

The activities of the Ukrainian authorities of that time did not go unnoticed by the world media. It is going about adopting legislative amendments on 16 January 2013 (which were later repealed) by the Verkhovna Rada, which automatically turned Ukraine into a dictatorship. These events were comment- 
ed on by The Independent, Financial Times, The New York Times, BBC, The Guardian, Deutsche Welle, Die Welt, Spiegel-online. For example, in the article, Ukraine Passes Anti-protest Laws, The Independent listed in detail most of the introduced changes in legislation and the provided penalties (Polityuk, 2014).

A significant role in Euromaidan was played by social networks, which activists used to establish communication better. However, we should not consider that only social networks and the Internet became key elements in the course of the revolution. The use of the Internet only created additional opportunities. The decisive role in Euromaidan belonged to the active position of citizens who went to rallies and protests in the real world.

The social network Facebook became an active information platform for Ukrainians. On this network, the first call for mobilisation of civilians, asking them not to be indifferent and join the protests, was made. Almost 140,000 Facebook users followed the news of the EuroMaidan community, and 18,000 followed Euromaidan SOS. The EuroMaidan community has become a real guide to news gathered from all independent sources, both Ukrainian and foreign. The important information from reputable Facebook users was also published on the page (Chornokondratenko, 2013).

On Facebook, public activists and media representatives published their analytics, created forecasts of the events, shared their impressions. Such information was often overwhelmed with emotions. The freedom of speech of the Internet space made activists a kind of newsmakers - their Facebook posts were more informative and truthful than traditional media ones. The social network structure and features contributed to its transformation into a blogosphere (the unlimited design of posts turns them into columns). Ordinary users entered into discussions, having the opportunity to share their thoughts, impressions, versions of events with others.

In addition, Facebook became a means of solving a wide range of issues: the groups such as KyivHost (in this group, participants offered housing to those who came to Euromaidan from other cities); Euromaidan SOS (the group provided legal support and published information about lost/found people, necessary assistance, organisation of events) were created. In this way, the users were able to draw the attention of foreign media to the events taking place in the country (YevromaidanSOS, n.d.).

However, information posts also had negative aspects, including the following: "clogging" the news feed with messages that are no longer relevant; spamming and panic-mongering; misinformation; distribution of fake pictures, and so on.

Journalists and analysts associate a significant number of stereotypes that existed both in Ukrainian society and abroad with the events of Euromaidan and its public perception.

Nowadays, the most effective approach to forming the country's international image is to create a multi-level context of associative relations with the country; within its framework, information about the state would be interpreted in a predetermined, desirable way. It should be noted that in the conditions of political, economic and social tension, unpredictability and uncertainty, the 
constant change in the geopolitical situation around Ukraine, the dangers and threats to national values, the real and forecast capabilities of the country to respond to these threats were not taken into account. The international information space, in its turn, was full of reports about Ukraine; the tense situation forced foreign media to fill their pages with "pro-Ukrainian" materials.

So, the ambiguous interpretation of the image of Ukraine in the information flow provides an opportunity to change or increase meanings, which are usually considered within culture as a process of constant expansion of semantic horizons. Thus, the cultural policy tools perform the function of forming a picture of the world for a person because it is the cultural component in the image communications of the state that covers the most incredible resource for effective image positioning in the international space of communications.

\section{Conclusions}

An image is an indicator of cultural meanings, a unique design, a mechanism of realising a national culture through a set of sign objectivations formed within a particular cultural and historical space and consolidated in individuals' mental representations. In 2010, the Western media formed the image of Ukraine, which had just embarked on the path of reforms (without appreciable progress), where corruption of the Ukrainian authorities had acquired a significant scale, human rights were not observed, the population was poor and which poses an investment risk. This negative image affected the fact that much fewer people came to the Euro 2012 championship significantly. Some European officials questioned the holding of the championship or refused to visit the country, which worsened the development of the tourism sector, the promotion of national cultural heritage and the investment climate. However, Ukrainians showed themselves as a friendly and hospitable country; Kyiv was recognised as one of the most vibrant cities in the world. The Revolution of Dignity of 2013-2014 shook the whole world once again, and the phenomenon of Euromaidan became international. The image of Ukraine changed in the course of these events completely. In the West, they spoke of Ukraine as an independent free country and the "unconquerable Ukrainians".

So, the image of Ukraine continues to be at the stage of reformatting significant cultural, political, economic changes are taking place, although the situation remains unstable and quite critical. But a properly structured state cultural policy and the use of image-making tools will help the country to embark on the path of political stabilisation, which, in its turn, will strengthen and form a positive image.

\section{References}

Bidder, B. Von, \& Eichhofer, A. (2012, April 12). Fußball-EM in der Ukraine: ZuGastbei der Mafia [European Football Championship in Ukraine: Guest of the Mafia]. Der Spiegel.https://www.spiegel.de/reise/staedte/ukraine-zimmerpreise-explodierenvor-fussball-em-a-826787.html [in German]. 
Bohush, D. (2010, February 23). Mizhnarodnyi imidzh Ukrainy: problemy i perspektyvy [International Image of Ukraine: Problems and Prospects]. Ukrainska pravda. https://blogs.pravda.com.ua/authors/bogush/4b843f0bd3e45/ [in Ukrainian].

Chornokondratenko, M. (2013, December 6). Fenomen Yevromaidanu u media [The Phenomenon of Euromaidan in the Media]. Yevropeiska observatoriia zhurnalistyky. http://ua.ejo-online.eu/1583/ [in Ukrainian].

Demokratychni initsiatyvy. (2013, December 27). Hromadska dumka: pidsumky 2013 roku [Public Opinion: Results of 2013]. https://dif.org.ua/article/gromadskadumka-pidsumki-2013-roku [in Ukrainian].

Gorshkova, A. A. (2001). Politicheskii risk i metody ego optimizatsii [Political Risk and Methods of its Optimisation]. In V. D. Zotov (Ed.), Aktual'nye problemy politologii [Actual Problems of Political Science] (pp. 139-142). MAKS Press [in Russian].

Harvey, O. (2012, June 18). Fans' Coffin Demo at Sol. The Sun. https://www.thesun.co.uk/ archives/news/697833/fans-coffin-demo-at-sol/ [in English].

Hasanenko, N. (2002, July 24). Politychnyi ryzyk investytsiinoi diialnosti v Ukraini [Political Risk of Investment Activity in Ukraine]. Delo.ua. https://investgazeta.delo.ua/ ekonomika/politichnij-rizik-investicijno-255865/ [in Ukrainian].

Hastynshchykov, V. (2010). Uzahalnennia mizhnarodnoho dosvidu pry vyznachenni shliakhiv vkhodzhennia Ukrainy u svitovyi informatsiinyi prostir [Generalisation of International Experience in Determining the Ways of Ukraine's Entry Into the World Information Space]. Bulletin of the Book Chamber, 12, 31-35 [in Ukrainian].

Holt, O. (2012, June 26). Absence of Ukrainian Racism Proves we Should Sort Out Our Own Problems Before Preaching to Others. Daily Mirror. www.mirror.co.uk/sport/ football/news/oliver-holt-column-on-euro-2012-941435 [in English].

Jones, F.-O. (2012, June 21). 36 Hours in Kiev, Ukraine. The New York Times. https:// www.nytimes.com/2012/06/24/travel/36-hours-in-kiev-ukraine.html [in English].

Ol'shanskii, D. V. (2002). Politiko-psikhologicheskii slovar' [Political and Psychological Dictionary]. Akademicheskii Proekt [in Russian].

Polityuk, P. (2014, January 17). Ukraine Passes Anti-Protest Law. The Independent. http://www.independent.co.uk/news/world/europe/ukraine-passes-antiprotestlaw-9066054.html [in English].

Savchenko, M. (2012, August 17). Poslevkusie Evro-2012: ukraintsy gordyatsya rodinoi i zhdut novykh sportivnykh prazdnikov [Aftertaste of Euro 2012: Ukrainians are Proud of Their Homeland and Look Forward to New Sports Events]. KP v Ukraine. https://kp.ua/sport/352118-poslevkusye-evro-2012-ukrayntsy-hordiatsiarodynoi-y-zhdut-novykh-sportyvnykh-prazdnykov [in Russian].

Shchurko, O. (2007, May 10-11). Chynnyky formuvannia mizhnarodnoho obrazu derzhavy: pryntsypy klasyfikatsii [The Factors of Formation of the International Image of the State: The Principles of Classification]. In Politychna nauka v Ukraini: stan i perspektyvy [Political Science in Ukraine: Status and Prospects], Proceedings of the All-Ukrainian Scientific Conference (pp. 261-268). Tsentr politychnykh doslidzhen [in Ukrainian].

Shvets, O. V. (2006). Formuvannia politychnoho imidzhu Ukrainy v mizhnarodnomu informatsiinomu prostori [Formation of Ukraine's Political Image in the International Information Space] [PhD Dissertation]. Taras Shevchenko National University of Kyiv [in Ukrainian]. 
Svitovi ZMI: 10 holovnykh mesedzhiv pro Ukrainu i Yevro-2012 [World Media: 10 Main Messages About Ukraine and Euro-2012]. (2012, 16 July). Galinfo. https:// galinfo.com.ua/news/svitovi_zmi_10_golovnyh_mesedzhiv_pro_ukrainu_i_ yevro2012_114200.html [in Ukrainian].

Yevromaidan [Euromaidan]. (2020, June 7). In Wikipedia. https://uk.wikipedia. org/w/index.php?title=\%D0\%84\%D0\%B2\%D1\%80\%D0\%BE\%D0\%BC\%D0\% B0\%D0\%B9\%D0\%B4\%D0\%B0\%D0\%BD\&oldid=32564196 [in Ukrainian].

YevromaidanSOS [@EvromaidanSOS]. (n.d.). Posts [Facebook profile]. Facebook. Retrieved January 9, 2021, from https://www.facebook.com/EvromaidanSOS [in Ukrainian].

Zubyk, O. (n.d.). Imidzh Ukrainy: pohliad z-za mezh [Image of Ukraine: a Look From Abroad].Vseukrainska ekspertna merezha.http://www.experts.in.ua/baza/analitic/ index.php?ELEMENT_ID=11063 [in Ukrainian].

\section{ЕВОЛЮЦІЯ КУЛЬТУРОЛОГІЧНОЇ МОДЕЛІ ІМІДЖУ УКРАЇНИ В МІЖНАРОДНОМУ ІНФОРМАЦІЙНОМУ ПРОСТОРІ}

\section{Кошелєва Оксана Борисівна}

Старший викладач, ORCID: 0000-0002-1653-2103, renisenb@ukr.net, Київський національний університет культури і мистецтвв, Київ, Україна

Мета статті - визначити соціокультурні детермінанти трансформації закордонного іміджу України під впливом внутрішньо- та зовнішньополітичних подій і стан його висвітлення в інформаційному просторі; з'ясувати еволюцію культурологічної моделі іміджу України в міжнародному інформаційному просторі. Методологія дослідження полягає у використанні міждисциплінарних методів і підходів для виявлення інформаційних та комунікаційних технологій, спрямованих на формування міжнародного іміджу України; принцип історизму дав змогу визначити етапи зміни інформаційного простору і трансформації геополітичної ситуації довкола України; структурний та метод порівняння застосовувалися для визначення позицій міжнародних ЗМІ щодо України, їхнього впливу на формування її іміджу. Наукова новизна дослідження визначається в представленні іміджу України як вираження ментальності окремої культурно-історичної спільноти, показника культурних смислів, унікальної конструкції, механізму реалізації національної культури через сукупність знакових об’єктивацій, що формуються в межах окремого культурноісторичного простору та закріплені в ментальних уявленнях індивідів. Висновки. Доведено, що негативний імідж України, створений західними ЗМІ, суттєво вплинув на розвиток її туристичної сфери, популяризацію національних культурних надбань та інвестиційний клімат. Сучасний імідж України проходить стадію переформатування; відбуваються значні культурні, політичні, економічні зміни. Культурологічну модель позитивного іміджу України в міжнародному інформаційному просторі визначає 
правильно вибудувана державна культурна політика та ефективне використання сучасних іміджетворчих інструментів, що здатні вивести іï на шлях культурної, політичної й економічної стабілізації.

Ключові слова: міжнародний імідж; національна культура; інформаційний простір; Україна; культурна політика; ЗМI

\section{ЭВОЛЮЦИЯ КУЛЬТУРОЛОГИЧЕСКОЙ МОДЕЛИ ИМИДЖА УКРАИНЫ В МЕЖДУНАРОДНОМ ИНФОРМАЦИОННОМ ПРОСТРАНСТВЕ}

\section{Кошелева Оксана Борисовна}

Старший преподаватель,

ORCID: 0000-0002-1653-2103, renisenb@ukr.net,

Киевский национальный университет культуры и искусств,

Киев, Украина

Цель статьи - определить социокультурные детерминанты трансформации заграничного имиджа Украины под влиянием внутри- и внешнеполитических событий и их освещения в информационном пространстве; выяснить эволюцию культурологической модели имиджа Украины в международном информационном пространстве. Методология исследования заключается в использовании междисциплинарных методов и подходов для выявления информационных и коммуникационных технологий, направленных на формирование международного имиджа Украины; принцип историзма позволил определить этапы изменения информационного пространства и трансформации геополитической ситуации вокруг Украины; структурный и метод сравнения применялись для определения позиций международных СМИ по отношению к Украине, их влияния на формирование ее имиджа. Научная новизна исследования определяется в представлении имиджа Украины как выражения ментальности отдельной культурно-исторической общности, показателя культурных смыслов, уникальной конструкции, механизма реализации национальной культуры через совокупность знаковых объективаций, формируемых в рамках отдельного культурно-исторического пространства и закрепленных в ментальных представлениях индивидов. Выводы. Доказано, что негативный имидж Украины, сформированный западными СМИ, существенно повлиял на развитие ее туристической сферы, популяризацию национальных культурных ценностей и инвестиционный климат. Современный имидж Украины проходит стадию переформатирования; происходят значительные культурные, политические, экономические изменения. Культурологическую модель позитивного имиджа Украины в международном информационном пространстве определяет правильно выстроенная государственная культурная политика и эффективное использование современных имиджевых инструментов, которые способны вывести ее на путь культурной, политической и экономической стабилизации.

Ключевые слова: международный имидж; национальная культура; информационное пространство; Украина; культурная политика; СМИ 